\title{
Climate change mitigation and agriculture: measures, costs and policies - A literature review
}

\author{
Lankoski Jussi ${ }^{1}$, Lötjönen Sanna² and Ollikainen Markku² \\ ${ }^{1}$ OECD Trade and Agriculture Directorate, Agricultural and Resource Policies Division, 2 rue Andre Pascal, 75116 Paris, France \\ ${ }^{2}$ Department of Economics and Management, University of Helsinki, P.O. Box 27, Fl-00014 University of Helsinki, Finland \\ e-mail: markku.ollikainen@helsinki.fi
}

\begin{abstract}
We review the literature on climate change mitigation in agriculture with a focus on the use of climate policy instruments to incentivize the adoption of greenhouse gas mitigation measures. We develop an economic model characterizing the production decisions in animal and crop production farms and link our discussion on policy instruments to them. We review mitigation measures and their cost-effectiveness in reducing emissions. Given the multiple sources of agricultural emissions, the literature finds carbon taxes and emissions trading to perform best. The challenges involved in measuring and verifying changes in emissions make the implementation of policies targeting all sources of emissions difficult. Second-best policies addressing a subset of emissions, such as those from ruminants or mineral fertilizers, are more feasible but less efficient. Carbon sequestration in arable soils, while technically promising, faces the problems of heterogeneity in sequestration capacity, measurement, verification and permanence of sequestration. The variation of estimates on emissions reduction, abatement costs and differences in model simulations is large. A better basis for policy designs is needed.
\end{abstract}

Key words: GHG emissions, carbon sinks, enteric fermentation, carbon tax, emissions trading, abatement subsidy

\section{Introduction}

Agriculture as a sector contributes substantially to climate change. Annual direct emissions from agriculture were approximately 5.0-5.8 $\mathrm{GtCO}_{2}$ eq (carbon dioxide equivalent) during the period 2000-2010, representing $11 \%$ of the global anthropogenic greenhouse gas (GHG) emissions, which amount to $49 \mathrm{GtCO}_{2}$ eq (Smith et al. 2014). Land use and land use change are responsible for an additional 4.3-5.5 $\mathrm{GtCO}_{2}$ eq of annual emissions during this period, much of which stems from agriculture (Smith et al. 2014). The total annual contribution of the agriculture, forestry and land use (AFOLU) sector to global emissions is $10-12 \mathrm{GtCO}_{2} \mathrm{eq}$, representing $24 \%$ of global emissions.

The main direct agricultural GHG emissions are nitrous oxide $\left(\mathrm{N}_{2} \mathrm{O}\right)$ emissions from soils, fertilizers, and manure from grazing animals and methane $\left(\mathrm{CH}_{4}\right)$ emissions stemming from ruminants and paddy rice cultivation. Both GHGs have a significantly higher global warming potential than carbon dioxide $\left(\mathrm{CO}_{2}\right)$. Of all agricultural direct non$\mathrm{CO}_{2}$ emissions, $80 \%$ are from livestock, with ruminants accounting for more than $80 \%$ of the total livestock emissions (Havlik et al. 2014). Given that poultry and swine husbandry play a minor role in GHG emissions compared to livestock, in this review, we focus solely on ruminants and crop production.

The global human population is projected to increase by 2 billion by 2050, most of which will occur in developing countries with relatively high income elasticities for food demand. As a consequence, food demand could increase by more than $70 \%$, even under the assumption of moderately high income growth (Blandford and Hassapoyannes 2018). The demand for emissions-intensive livestock products is projected to rise more rapidly than the demand for crop products. This could increase the share of animal products in human diets and livestock and crop production by $80 \%$ and $48 \%$, respectively, by 2050 . Estimates suggest that this development will increase agricultural non- $\mathrm{CO}_{2}$ emissions by 76\% relative to 1995 levels (Havlík et al. 2014, Bennetzen et al. 2016).

GHG mitigation potential in the agriculture sector can generally be decomposed into technical, economic, and socially and politically constrained potential (OECD 2019). The technical potential is defined as the maximum mitigation possible with the full implementation of all available mitigation options and ignoring all barriers to adoption. The economic potential indicates the costs and benefits of different mitigation measures showing mitigation potential for a given carbon price. Political and social barriers restrict the use of mitigation measures and are related to possible adverse distributional impacts of policy options (Wreford et al. 2017, OECD 2019). 


\section{AGRICULTURAL AND FOOD SCIENCE}

J. Lankoski et al. (2020) 29: 110-129

The global technical mitigation potential of the agriculture sector in 2030 is estimated to be $5500-6000 \mathrm{MtCO}_{2}$ eq $\mathrm{yr}^{-1}$, with a $95 \%$ confidence interval around this mean value of $300-11400 \mathrm{MtCO}_{2}$ eq $\mathrm{r}^{-1}$ (Smith 2012). This estimate is based on the maximum use of available emissions reduction and soil carbon sequestration measures. Regarding the global economic potential, the Assessment Report of the IPCC, drawing on results from a number of studies (Smith et al. 2008, Golub et al. 2009, McKinsey and Company 2009, Rose et al. 2012), found that emission reductions for agriculture of $0.03-2.6 \mathrm{GtCO}_{2}$ eq are possible at USD 50 per ton of $\mathrm{CO}_{2}$ eq and reductions of $0.2-4.6$ $\mathrm{GtCO}_{2}$ eq at USD 100 per ton of $\mathrm{CO}_{2}$ eq in 2030 (Smith et al. 2014). A recent partial equilibrium assessment by Frank et al. (2018) calculated the non- $\mathrm{CO}_{2}$ mitigation potential in 2030 as $1 \mathrm{GtCO}_{2}$ eq at USD 25 per ton of $\mathrm{CO}_{2}$ eq and as $2.6 \mathrm{GtCO}_{2}$ eq in 2050 at USD 100 per ton of $\mathrm{CO}_{2}$ eq. The global potential for soil carbon sequestration is estimated to be high but exhibits considerable uncertainty. Smith (2016) reports the mean global potential for carbon sequestration in agricultural soils as $1.5 \mathrm{GtCO}_{2} \mathrm{yr}^{-1}$ and $2.6 \mathrm{GtCO}_{2} \mathrm{yr}^{-1}$, at carbon prices of USD 20 per ton of $\mathrm{CO}_{2}$ eq and USD 100 per ton of $\mathrm{CO}_{2}$ eq, respectively.

Barriers to the uptake of all technical and economic GHG mitigation potential in the agriculture sector are plentiful. Wreford et al. (2017) identify as a farm-level barrier the actual or perceived lack of financial benefits from the adoption of mitigation measures and as a national-level barrier the actual or perceived effects of mitigation measures on production. Additionally, insufficient information and education, transaction costs, and social and cultural factors may turn out to be significant barriers to the adoption of mitigation practices (Wreford et al. 2017). Using interviews and workshops, Kipling et al. (2019) identified the following barriers and challenge categories for Welsh livestock production: practical limitations, knowledge limitations, interests and cognitive limitations.

Climate policy is now entering agriculture at a larger scale. This change raises the key question of how to create proper incentives and overcome barriers to the adoption of abatement measures. Defining the most effective measures and their costs is crucial for choosing economic instruments to promote the reduction of emissions and to increase agricultural carbon sinks. The marginal abatement cost curve (MACC) approach has been widely used to compile information on the costs and mitigation potential of GHG mitigation measures. Eory et al. (2018) review the current state and future projections of using GHG MACCs in agriculture and identify the key limitations or challenges related to their use: how to set system boundaries, choose measures, find data, and define the baseline and possible co-benefits and tradeoffs of the selected measures. They also suggest the use of different incentives depending on the chosen measures ranging from providing knowledge to cost-negative measures to financial support for high-cost measures and mandatory requirements. The abovementioned reviews do not, however, specifically focus on the use of climate policy instruments. Additionally, Jones et al. (2013), who review bioenergy, conservation programs and R\&D as means to mitigate GHG emissions from agriculture in the US, focus on policy programs, not on policy instruments. Thus, an extensive review on the use of climate policy instruments is missing.

The aim of this paper is to fill the gap in the literature. Our survey is on the use and impacts of climate policy instruments in agriculture. We believe that this discussion is missing from the literature. The earlier review-type papers (e.g., Gonzales-Ramirez et al. 2012, Jones et al. 2013, MacLeod et al. 2015, Eory et al. 2018) focus more on measures and costs but discuss policy instruments in a more passive or narrow way. We discuss measures and their efficiency in reducing GHG emissions. We pay special attention to how they affect crop and animal production, as they are sources of different GHGs requiring the use of different mitigation measures. We outline a heuristic economic model characterizing the production decisions in animal and crop production farms and show how the use of alternative climate policy instruments would enter a private farmer's profit function. Furthermore, we link our discussion of mitigation measures and policy instruments to the production lines and interactions between them. While our discussion of climate policy instruments is general, we mostly rely on data from boreal and temperate agriculture.

The remainder of the paper is structured as follows. Section two presents the heuristic economic model for guiding our review and discussion of mitigation measures and policy instruments. Section three focuses on the effectiveness and cost-effectiveness of potential mitigation measures in crop and animal production. The fourth section discusses policy instruments to promote the adoption of mitigation measures and challenges related to the measurement, reporting and verification (MRV) of GHG emissions reductions. A final section summarizes our findings. 


\section{AGRICULTURAL AND FOOD SCIENCE}

\section{Mitigation from an economic and policy angle: a framework}

The main production lines of agriculture are, in broad terms, crop production and livestock production, which includes milk and beef production. In crop production, the management unit is a land parcel, and the key choices comprise the allocation of land to cultivated crops, the choice of a tillage method, and fertilizer use. Livestock production differs from crop production in many ways: 1 ) the primary production unit is the production animal, with arable farmland mostly playing a supporting role of providing animal feed, and 2) the production and use of manure. Manure is a costly byproduct and, at the same time, a valuable source of fertilizer for crops. The high cost of manure transportation affects decisions on its use. In mixed crop and livestock farms, manure is used as a fertilizer in the fields, and it is possibly augmented by mineral fertilizers. Provided that nutrient content in manure can be impacted by changing animal diet, manure creates a link between decisions concerning livestock and cultivation. Once this link is missing, livestock production and cultivation become entirely separate production lines (see Lötjönen et al. 2020 for the proof). Our focus here is on linking agricultural decision-making in crop and livestock production to GHG emissions and showing how private farmers can be impacted by climate policies. We adopt our approach from Lötjönen et al. (2020).

\section{Model setup}

Key sources of GHG emissions from livestock are enteric fermentation and manure management, both emitting $\mathrm{CH}_{4}$ (Gerber et al. 2013). Manure storage and spreading cause $\mathrm{N}_{2} \mathrm{O}$ emissions. Additionally, during manure storage and spreading, some nitrogen $(\mathrm{N})$ evaporates as ammonia $\left(\mathrm{NH}_{3}\right)$, which is not a GHG, but part of the $\mathrm{NH}_{3}$ transforms into indirect $\mathrm{N}_{2} \mathrm{O}$ emissions. Volatilized $\mathrm{N}$ reduces manure $\mathrm{N}$ content and thus affects cultivation decisions. Additionally, spreading technology and diet slightly impact GHG emissions. From the cultivation side, feed production causes significant amounts of emissions (Gerber et al. 2013). GHG sources from crop production include soil emissions $\left(\mathrm{CO}_{2}\right.$ and $\left.\mathrm{N}_{2} \mathrm{O}\right)$, emissions from mineral fertilizer production and application, and the use of machinery.

We outline our framework in a simple way with the help of Figure 1, which focuses on milk and beef production and shows the links between crop and livestock production and the key points of decision-making. In the absence of climate policies, private farmers neglect the climate impacts of production. These decisions are illustrated in Figure 1 by rectangles covering diet, output and manure management. Diet consists of concentrate feed and silage. Manure is stored and spread on fields (and if needed, mineral fertilizer is also bought). Ovals indicate how GHG impacts relate to private production decisions, as explained above.

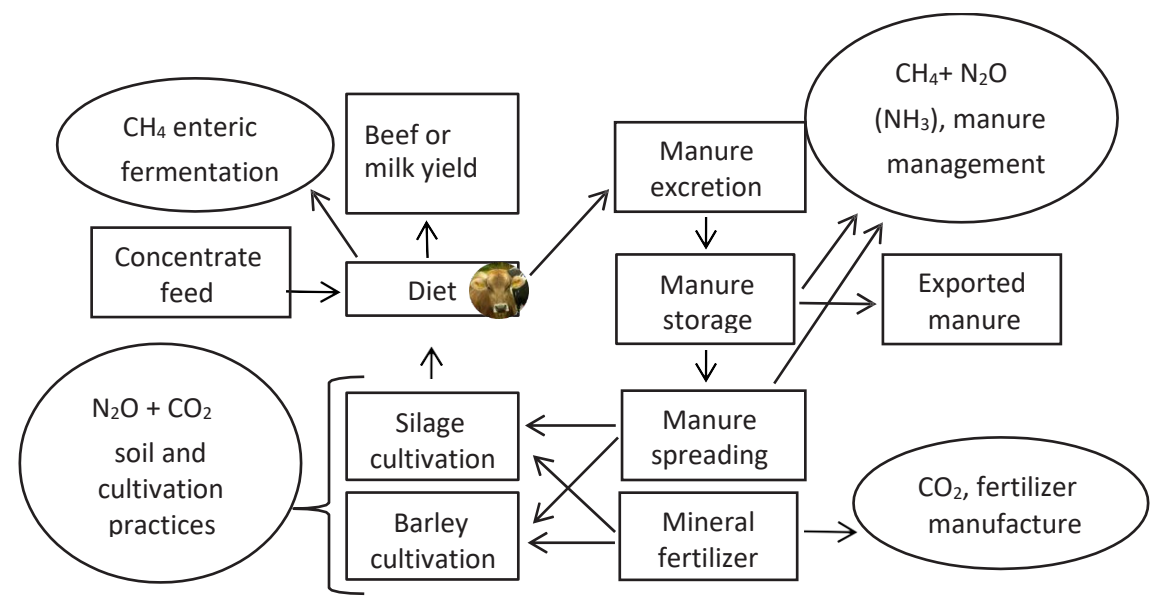

Fig. 1. Livestock production and GHG emissions. Modified from: Lötjönen et al. (2020).

We now take a step forward and provide a heuristic analytical framework to facilitate our discussion of measures and especially economic instruments. This framework is a shortened and simplified version of the full livestock model developed by Lötjönen et al. (2020). Let $H$ denote the number of livestock and $\Omega H$ the net revenue from selling livestock products (milk or beef), while $i(H)$ denotes investment and other costs from barn, manure management and other facilities. Denote revenue from silage and cereal cultivation by $\Pi^{s}$ and $\Pi^{c}$, respectively. To keep the discussion general, we omit a more detailed description of cultivation. The private revenue from livestock production is given by 


\section{AGRICULTURAL AND FOOD SCIENCE}

$$
R=[\Omega(v) H-i(H)]+\left[\Pi^{s}(N(r))+\Pi^{c}(N(r))\right]
$$

The first bracket denotes the net revenue from animal production, and the second bracket denotes profits from crop production ( $s$ denotes silage and $c$ cereal crops). The net revenue per animal is a function of concentrate feed intake $v$, which determines the diet. Revenue from cultivation is a function of applied nitrogen, $N$ [its source being either manure, $m(r)$, or mineral fertilizer, $I(r)]$ application at distance $r$, and the critical radius, that is, the outer limit from the farm center for silage cultivation $r^{s}$. Fertilization, land allocation, and diet with herd size $H$ constitute the decision variables in the model.

We next develop the social perspective on private farmers' decisions. Let $E$ denote the GHG emissions from enteric fermentation and manure storage per animal unit and $e^{s}$ and $e^{c}$ denote GHG emissions from crop production, silage and cereals, respectively (including emissions related to soil and fertilization with both manure and mineral fertilizers). We postulate a (constant) marginal valuation of climate damage from GHG emissions and denote it by $d$. Then, we can express social welfare from livestock production as shown in equation (1b).

$$
W=[\Omega(v) H-d E H-i(H)]+\left[\Pi^{s}(N(r))-d e^{s}+\Pi^{c}(N(r))-d e^{c}\right]
$$

Equation (1b) provides the key points on which climate policy instruments should be levied: GHG emissions from enteric fermentation and manure, soil emissions and emissions from the use of mineral fertilizers.

In the next two sections, we provide the optimality conditions for the maximization of private profits (1a) and social welfare (1b). A comparison of private and social optima indicates the potential entry points for climate policy instruments. In the fourth section concerning policy instruments, we discuss in detail through which channels the alternative instruments work.

\section{Decisions in animal production}

Decisions in animal production entail the choice of herd size and associated investments in barns and manure storage and the choice of diet. Production also involves some choices of technologies, such as manure storage (covered with different materials or uncovered). Unlike other decisions, these are discrete choices.

The socially and privately optimal herd sizes, derived from equations (1a) and (1b), are determined by the equality of marginal revenues and marginal costs, as equations (2a) for society and (2b) for private farmers suggest:

$$
\begin{aligned}
& \Omega-d E-i^{\prime}(H)=0, \\
& \Omega-i^{\prime}(H)=0 .
\end{aligned}
$$

As society accounts for the climate impacts from enteric fermentation and manure storage and application, the socially optimal herd size is smaller than the private one. The implication of equations $(2 a)-(2 b)$ for the use of policy instruments is clear: in the absence of abatement possibilities, instruments should reduce herd size. Inventing abatement technologies to reduce $\mathrm{CH}_{4}$ emissions would allow for higher animal numbers.

The optimal diet is determined by the choice of concentrate feed, $v$, which in turn determines the (possibly) required silage use through the properties of the intake function (not discussed here). Additionally, diet affects the nutrient content and amount of manure excreted, and this connects the optimal choices in diet and cultivation.

The optimality conditions for the social (3a) and private (3b) choices are as follows (subscripts denote derivatives):

$$
\begin{aligned}
& \left(\Omega_{v}-d E_{v}\right) H+\left[\Pi_{v}^{s}-d e_{v}^{s}+\Pi_{v}^{c}-d e_{v}^{c}\right]=0, \\
& \Omega_{v} H+\left[\Pi_{v}^{s}+\Pi_{v}^{c}\right]=0 .
\end{aligned}
$$

Interestingly, the choice of concentrate feed impacts at the margin not only animal production and associated feeding costs but also drives both silage and manure stocks (see Lötjönen et al. 2020 for details). This marginally affects the profits from silage and cereal cultivation. Equation (3a) illustrates how complicated optimal climate policy in the agriculture sector could actually be. Ideally, policy instruments should impact diet, as it impacts GHG emissions both directly and indirectly via land allocation and fertilization decisions. Assessment of the magnitude 


\section{AGRICULTURAL AND FOOD SCIENCE}

J. Lankoski et al. (2020) 29: 110-129

of the diet's impact on enteric fermentation, land allocation and fertilization plays a crucial role in defining the need to control diet with policy instruments.

If the impact of concentrate feed on manure nutrients is absent (or very small), the cultivation decisions are separate from animal production decisions. Now, equation (3a) for society and (3b) for private farmers reduce to

$$
\begin{aligned}
& \left(\Omega_{v}-d E_{v}\right) H=0, \\
& \Omega_{v} H=0 .
\end{aligned}
$$

This illustrates the case where crop production and animal production are separable and both are optimized separately with one condition - that there must be enough silage for the herd. However, again, the choice of diet should be part of ideal climate policy, as it affects methane emissions from enteric fermentation.

\section{Decisions in crop production}

Typical decisions in crop production entail the choice of crops, fertilization, land allocation and tillage methods. The tillage method is a discrete technology choice, while the others are continuous. The optimal fertilizer application in each location entails the choice between mineral and manure fertilizers and their optimal rate of application. For society, the latter is determined by the equality of the value of the marginal product to the marginal social costs of the fertilizer comprising the input costs and the sum of the marginal climate damages. Mineral fertilizer has a constant unit cost (price) with a slightly increasing application cost with distance, while for manure, the transport cost clearly increases with distance. The critical radius for manure application, $r^{m}$, defines the optimal distance at which the farmer shifts from manure to mineral fertilizer application. The determination of the switching point requires some calculation (see Lötjönen et al. 2020), but it can be formulated rather simply for both society (5a) and private farmers (5b):

$$
\begin{aligned}
& \frac{a-C+d e^{i}\left(m, r^{m}\right)}{\theta^{N}}=\frac{p^{l}+d e^{i}\left(l, r^{m}\right)}{\varepsilon^{N}}, \\
& \frac{a-C}{\theta^{N}}=\frac{p^{l}}{\varepsilon^{N}},
\end{aligned}
$$

where $a$ denotes manure transportation and application costs, $C$ the cost of exporting manure from the farm, $e^{i}$ (with $\left.i=s, c\right)$ cultivation-related emissions from silage and cereal cultivation, $p^{\prime}$ the mineral fertilizer price, and $\theta^{N}$ and $\varepsilon^{N}$ represent the manure and mineral fertilizer $N$ contents, respectively. As manure and mineral fertilizer are perfect substitutes in crop production, they are not used jointly; the lowest-cost fertilizer is always chosen. On field parcels close to the farm center, manure is applied exclusively until the switching point, where mineral fertilizer becomes less costly. Beyond this, mineral fertilizer is applied exclusively, while the optimal $\mathrm{N}$ application rate is equal for both fertilizers at the critical radius. As a result, the $\mathrm{N}$ application rate is always higher on parcels under manure fertilization, except at the point of indifference. This holds true for both private and social solutions. In any case, climate policy should account for the GHG emissions from fertilization giving grounds, for instance, for taxing nitrogen applications, as we shall see in the fourth section discussing policy instruments.

Finally, land is allocated over the gradient from the farm center between the crops according to their profitability. Silage is more profitable closer to the farm center due to its increasing transport cost, but there is a distance at which cereal crops become equally profitable according to equation (6a) for society and (6b) for private farmers:

$$
\Pi^{s}-d e^{s}=\Pi^{c}-d e^{c},
$$

$$
\Pi^{s}=\Pi^{c}
$$

Given that the net GHG emissions from soils are higher for cereal production due to the lack of soil cover, the social optimum (6a) entails a larger land area allocated to silage than the private optimum (6b). 


\section{AGRICULTURAL AND FOOD SCIENCE}

J. Lankoski et al. (2020) 29: 110-129

\section{First-best policy for animal and crop production}

Equations (1a) - (6b) demonstrate that the privately and socially optimal decisions in both livestock and crop production differ. Society accounts for climate impacts, whereas private farmers neglect them in the absence of policies. This is reflected in larger herd size, higher use of concentrates, higher fertilizer intensity and land allocation and calls for climate policies that should change private decisions in livestock and crop production towards the social optimum. In general, the optimal first-best climate policy for agriculture entails a uniform carbon tax, $t$, equal to the marginal climate damage, levied on all sources of GHG emissions, as shown by equation (7):

$$
\pi=[\Omega H-t E H-i(H)]+\left[\Pi^{s}-t e^{s}+\Pi^{c}-t e^{c}\right]
$$

Under this tax, private farmers have incentives to reduce all GHG emissions - provided that all emissions can be measured and decisions can be monitored. In practice, this may be difficult due to incomplete and asymmetric information. Therefore, much of the literature focuses on second-best policies targeting one or some sources of GHG emissions. Equation (7) and the above analysis have identified a number of entry points at which policy instruments should impact farmers' behavior: herd size and the means of abating $\mathrm{CH}_{4}$ emissions, the choice of diet, and the use of manure and mineral fertilizers. These choices impact the land allocation between crops and thereby soil emissions. The second-best instruments levied on herd size, diet or fertilization will impact land allocation only indirectly.

To tailor second-best policies, society needs to have an understanding of the mitigation measures available for farming and their costs and possible co-benefits. Drawing on this information, policies may relate to inputs, production animals or (discrete) technologies. We first focus on measures and their impacts on emissions and associated costs and then turn to policy instruments.

\section{Measures to mitigate climate impacts of crop and livestock production}

Many GHG mitigation options are readily available for crop and livestock production, including reducing nitrogen fertilizer use, adopting reduced or no-till methods, the conversion of arable land to grassland, changing livestock diet and adopting manure management technologies that reduce GHG emissions (MacLeod et al. 2015). However, only a few of these options belong to the so-called win-win solutions, meaning that they increase farm profits while reducing GHG emissions. Thus, the adoption of climate measures typically requires policy instruments or markets that incentivize and accelerate their uptake, which we will discuss separately later in this paper.

\section{Mitigation measures}

By adopting mitigation measures, a private farmer can reduce agricultural emissions and climate damage and, for instance, avoid carbon taxes in equation (7). Starting with livestock, a reduction in herd size is an extreme measure that impacts emissions directly by lowering $\mathrm{CH}_{4}$ emissions from enteric fermentation and indirectly by affecting emissions related to feed production and manure management. Altering the share of concentrates in the diet may increase or decrease emissions from enteric fermentation depending on the starting point. Increasing concentrate intake from the privately optimal value of $16.09 \mathrm{kgDM}_{\text {day }}{ }^{-1}$ reduces $\mathrm{CH}_{4}$ emissions in Lötjönen et al. (2020; calculated based on Statistics Finland 2016). Adding fats to the diet decreases $\mathrm{CH} 4$ emissions from enteric fermentation; a 1\% increase in fat intake reduces $\mathrm{CH}_{4}$ emissions by approximately 4\% (MacLeod et al. 2015).

Covering manure storage decreases $\mathrm{CH}_{4}$ emissions but increases direct $\mathrm{N}_{2} \mathrm{O}$ emissions; however, the overall effect is a slight reduction in $\mathrm{CO}_{2}$ eq emissions (based on IPCC 2006, Grönroos 2014, Statistics Finland 2016). Injection technology for manure application clearly reduces the amount of $\mathrm{N}$ evaporated as $\mathrm{NH}_{3}$ relative to broadcast spreading ( $40 \%$ of manure $\mathrm{N}$ evaporates as $\mathrm{NH}_{3}$ with broadcast spreading, while only $9 \%$ of manure $\mathrm{N}$ evaporates with injection; Grönroos 2014). The impacts on $\mathrm{N}_{2} \mathrm{O}$ emissions between application measures are mixed, although it seems that injection spreading increases $\mathrm{N}_{2} \mathrm{O}$ emissions (Webb et al. 2010, Duncan et al. 2017). The importance of spreading technology stems mostly from water protection, as injection reduces $\mathrm{P}$ runoff by approximately $80 \%$ compared to broadcast spreading (Uusi-Kämppä and Heinonen-Tanski 2008). Additionally, the lower $\mathrm{NH}_{3}$ volatilization with injection spreading may provide economic incentives for the farmer to use the technology. 


\section{AGRICULTURAL AND FOOD SCIENCE}

J. Lankoski et al. (2020) 29: 110-129

A measure that goes beyond agriculture towards energy production is manure, which, with other organic materials, can be converted into biogas with anaerobic digestion. This technology reduces $\mathrm{CH}_{4}$ emissions from manure storage by capturing most of the emissions and transforming them into $\mathrm{CO}_{2}$ (MacLeod et al. 2015). Additional indirect emission savings stem from replacing fossil-based energy with renewable biogas, for instance, in road transport, but only if this substitution actually takes place. The volume of emissions saved is largely dependent on, for example, manure storage technology and temperature.

In crop production, reducing mineral fertilization decreases both emissions from fertilizer manufacturing and soil $\mathrm{N}_{2} \mathrm{O}$ emissions due to fertilization. Fertilization increases yields, which creates more crop residues and potentially increases soil carbon, but this effect does not outweigh emissions from manufacturing and soil $\mathrm{N}_{2} \mathrm{O}$. Precision application of fertilizers decreases $\mathrm{N}_{2} \mathrm{O}$ emissions from soils through the reduction of $\mathrm{N}$ fertilizer overapplication (ICF 2013). Buffer strips and wider buffer zones sequester carbon in the roots of the perennial plants and reduce land for cultivation; thus, cultivation-related emissions are avoided provided the lost land area is not cleared somewhere else (Lal 2004, Ervola et al. 2012). Buffer strips additionally reduce $\mathrm{N}$ from runoff water, which indirectly reduces $\mathrm{N}_{2} \mathrm{O}$ from leaching.

Leguminous crops and legumes in crop rotations reduce the need for fertilization, both in the current and the following cultivation period, as legumes fix nitrogen biologically from the air (Dequiedt and Moran 2015). Thus, emissions from fertilizer manufacture and fertilization-related soil emissions are reduced. Additionally, soil emissions from legume cultivation are estimated to be lower than, for example, those in cereal cultivation (Lötjönen and Ollikainen 2017; based on Heikkinen et al. 2013 and Regina et al. 2013).

A cover crop is a fast-growing crop cultivated at the same time as, or between plantings of, a main crop. Catch crops are a special type of cover crop cultivated for utilizing surplus nitrogen remaining after harvest of the main crop, and thus, they reduce $\mathrm{N}$ losses from the soil. Cover crops mitigate GHG emissions mainly by increasing the soil organic carbon (SOC) content (MacLeod et al. 2015). Catch crops have a marked potential to reduce indirect $\mathrm{N}_{2} \mathrm{O}$ emissions from $\mathrm{N}$ leaching, as they can reduce leaching by as much as 50\% (Valkama et al. 2015).

Conventional tillage is a tillage method that includes multiple soil disturbances, such as plowing and harrowing. Under no-till, the crops are directly sown without plowing. The effect of the tillage method varies across climate regions and soil types and across soil depths. In temperate regions, GHGs are estimated to decrease with minimum tillage and no-till (Meurer et al. 2018), but for example, in boreal regions, conventional tillage reduces GHGs in clay and loam soils (Ervola et al. 2012). However, several studies argue that the sequestration potential of notill is often overestimated (see, e.g., Powlson et al. 2014, Meurer et al. 2018, Ogle et al. 2019). In a review covering temperate and continental climates, Meurer et al. (2018) find that the effect of reduced tillage practices on SOC was limited to topsoil and that many studies neglect deeper soil layers. Powlson et al. (2014) remark that the increased $\mathrm{C}$ in topsoil may result from redistribution of $\mathrm{C}$ from deeper soil layers. They also stated that even periodic tillage would largely reduce the benefits gained from prior application of no-till. We conclude that the literature offers support to the argument that no-till promotes carbon sequestration in temperate and continental climates, but this support is tepid at best. In a boreal climate, the effect is the opposite.

Nitrification inhibitors reduce soil $\mathrm{N}_{2} \mathrm{O}$ emissions by slowing the conversion rate of nitrogen fertilizer ammonium to nitrate (Moran et al. 2008). As a result, the rate of conversion of nitrate to nitrous oxide decreases, and emissions of nitrous oxide decrease. Possible tradeoffs with nitrification inhibitors include an increase in $\mathrm{NH}_{3}$ emissions (Kim et al. 2012) and the contamination of products (Chen et al. 2014). Residue management refers to the incorporation of straw into the soil. In temperate regions, this increases soil organic matter and positively affects both nutrient cycling and carbon sequestration to the soil (McVittie et al. 2014). Green fallowing reduces soil emissions, and cultivation-related emissions are avoided (Ervola et al. 2012).

Table 1 condenses the impacts of these measures on the three main GHGs in boreal agriculture. Note that we include direct impacts of the measures only (e.g., reduction in herd size reduces manure excretion, but we do not account for reduced land area for feed production). In Table 1, "0" means no impact, a plus an increase, and a minus a decrease in emissions. Not surprisingly, most measures in livestock management impact $\mathrm{CH} 4$, while crop production impacts show up in $\mathrm{CO}_{2}$ and $\mathrm{N}_{2} \mathrm{O}$.

The next question is how costly the adoption of these measures actually is and by what instruments adoption can be achieved. We discuss these issues next. 
Table 1. Mitigation measures directly affecting GHGs and the direction of change in clay soil for each pollutant in boreal agriculture

\begin{tabular}{|c|c|c|c|}
\hline Dairy management & $\mathrm{CO}_{2}$ & $\mathrm{~N}_{2} \mathrm{O}$ & $\mathrm{CH}_{4}$ \\
\hline Herd size (reduction) & - & - & - \\
\hline Diet (increasing the share of concentrates from a private optimum) & 0 & 0 & - \\
\hline Diet (fat supplementation) & 0 & 0 & - \\
\hline Manure storage (shift from no to floating cover) & 0 & + & - \\
\hline Manure spreading (shift from broadcast to injection) & 0 & $?$ & 0 \\
\hline Anaerobic digestion & 0 & 0 & - \\
\hline \multicolumn{4}{|l|}{ Crop production } \\
\hline Fertilization (reduction) & - & - & 0 \\
\hline Precision nutrient application & 0 & - & 0 \\
\hline Buffer strips (increasing width) & - & 0 & 0 \\
\hline Legumes in crop rotations & - & - & 0 \\
\hline Catch crops & - & - & 0 \\
\hline Cover crops & - & - & 0 \\
\hline Tillage method (shift from conventional to no-till) ${ }^{2}$ & + & + & 0 \\
\hline Nitrification inhibitors & 0 & - & 0 \\
\hline Residue management (straw incorporation) & - & - & 0 \\
\hline Green fallow & - & - & - \\
\hline \multicolumn{4}{|c|}{$\begin{array}{l}+=\text { GHGs increased; }-=\text { GHGs decreased; } 0=\text { GHGs are not affected by the measure; } ?=\text { the result is not clear; } \mathrm{CO}_{2}= \\
\text { carbon dioxide; } \mathrm{N}_{2} \mathrm{O}=\text { nitrous oxide; } \mathrm{CH} 4=\text { methane } \\
{ }^{1} \text { Based on Lötjönen et al. (2020), Ervola et al. (2012, 2018), Valkama et al. (2015), Lötjönen and Ollikainen (2017), } \\
\text { MacLeod et al. (2015), and McVittie et al. (2014). }{ }^{2} \text { Estimates for temperate regions show a reduction in GHGs from a } \\
\text { shift to minimum tillage or no-till (McVittie et al. 2014) }\end{array}$} \\
\hline
\end{tabular}

\section{Cost-effectiveness of climate measures}

A single measure or a combination of measures can be used to mitigate GHG emissions. Given that each of them is costly, it is important to define how much private costs increase with a higher emissions reduction, i.e., with a higher abatement level. The answer to this question is given by marginal abatement cost functions, which have received considerable attention in the literature. The literature has derived marginal abatement cost curves by employing multiple methods, including bottom-up cost engineering, microeconomic modeling with exogenous prices, and equilibrium models with endogenous prices (MacLeod et al. 2015). The choice of methodology affects the cost estimates of mitigation measures.

Vermont and de Cara (2010) use a meta-analysis to show that the GHG mitigation costs provided by equilibrium models are consistently lower than those of supply-side microeconomic models. This is partly explained by the high degree of flexibility in resource allocation that the equilibrium models provide. However, price effects from markets may increase the opportunity costs of mitigation and thereby also the abatement cost estimates provided by equilibrium models. Moreover, at low emission prices (EUR $10 \mathrm{tCO}^{\mathrm{eeq}}{ }^{-1}$ ), the abatement rates of supply-side microeconomic models are $60 \%$ lower than those given by cost engineering approaches. This difference declines with higher emission prices and implies that the most abatement potential reported in engineering approaches comes from practices with low or even negative costs.

We now review the cost-effectiveness figures of the agricultural mitigation measures found in the literature. For abatement measures in dairy production, we report the reduction in GHG emissions per livestock unit (LU), and for crop production, we report the reduction per hectare and then divide these by the associated cost. Technically, this gives the unit cost of abatement and allows for a comparison of the cost-effectiveness of measures. We focus our discussion on boreal agriculture but collect figures from temperate regions to allow for comparison.

In dairy production, the cost-effectiveness estimates of abatement measures vary greatly within and between measures. Decrease of dairy herd size, that is, reducing dairy cow numbers would provide a large reduction in GHG emissions stemming from enteric fermentation and manure management, but the costs would also be high due to the reduced milk yield (Lötjönen et al. 2020). Among possible abatement measures, for fat supplementation, 


\section{AGRICULTURAL AND FOOD SCIENCE}

J. Lankoski et al. (2020) 29: 110-129

the cost estimates vary from approximately EUR 137 to 335 tCO2eq $^{-1}$ (Bates et al. 2009, Pellerin et al. 2013). Covering open manure storage with a floating cover reduces GHG emissions modestly at a relatively high cost (Lötjönen et al. 2020). The cost-effectiveness of anaerobic digestion is dependent on the type of digester. With a centralized digester, the costs of a $90 \%$ reduction in GHG emissions vary from negative numbers to more than EUR $100 \mathrm{tCO}^{\mathrm{eq}} \mathrm{q}^{-1}$ (Bates et al. 2009). Table 2 collects the cost-effectiveness estimates in dairy production.

Table 2. Cost-effectiveness of measures related to dairy production

\begin{tabular}{|c|c|c|c|c|}
\hline Abatement measure & 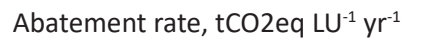 & Cost-effectiveness, EUR tCO2eq ${ }^{-1}$ & Source & Location \\
\hline $\begin{array}{l}\text { Decrease of dairy cow } \\
\text { herd size }\end{array}$ & $\begin{array}{l}2.6 \text { (yearly within a 3-year lactation } \\
\text { period) }\end{array}$ & $\begin{array}{l}519 \text { (yearly within a 3-year } \\
\text { lactation period) }\end{array}$ & Lötjönen et al. (2020) & Finland \\
\hline \multirow{2}{*}{$\begin{array}{l}\text { Fat supplementation/ } \\
\text { dietary lipids }\end{array}$} & $1 \%$ fat increase in ration reduces & $137-262$ & Bates et al. (2009) & EU27 \\
\hline & $4 \%$ of the $\mathrm{CH} 4$ emissions & $223-335$ & Pellerin et al. (2013) & France \\
\hline $\begin{array}{l}\text { Covered manure } \\
\text { storage (floating } \\
\text { cover) }\end{array}$ & 0.6 & 670 & Lötjönen et al. (2020) & Finland \\
\hline Anaerobic digestion & $90 \%$ abatement rate & $-48-130$ (centralized digester) & Bates et al. (2009) & EU27 \\
\hline
\end{tabular}

Turning to crop production, reduction rates and unit costs differ considerably, with leguminous crops being quite attractive at a cost below EUR $20 \mathrm{tCO}_{2} \mathrm{eq}^{-1}$ (Pellerin et al. 2013). Even more attractive is winter wheat with minimum tillage, which according to the literature entails negative costs (McVittie et al. 2014), that is, an increase in farm profit but with a modest abatement rate. This result is, however, indirectly challenged by finding that no-till causes high unit costs (McVittie et al. 2014). The literature provides mixed results concerning the cost of cover crops. They vary from approximately EUR 50 to $180 \mathrm{tCO}_{2} \mathrm{eq}^{-1}$ (Schulte et al. 2012, Pellerin et al. 2013, Posthumus et al. 2013, McVittie et al. 2014).

Table 3 collects the cost-effectiveness estimates for selected abatement measures that can be adopted in crop production to mitigate GHG emissions. Here, the number of measures is larger than in the case of livestock production. Furthermore, the costs of reducing GHG emissions are lower than in livestock farming, and we even observe negative costs here. Interestingly, Povellato et al. (2007) review the cost-effectiveness of different GHG mitigation measures in European agriculture and find that measures related to $\mathrm{CH}_{4}$ abatement are more cost-effective than changing management practices in crop cultivation (see also Lötjönen and Ollikainen 2019).

Table 3 reveals an interesting difference between no-till and minimum tillage in favor of the latter. The reason is that minimum tillage reduces costs associated with machinery. Another notable feature is that the costs of cover crops differ considerably, being generally higher than those of many other measures. In general, the wide range of estimates may reflect geographic differences, variation in modeling choices or uncertainty in the determination of costs.

Table 3. Cost-effectiveness of measures related to crop production

\begin{tabular}{|c|c|c|c|c|}
\hline Abatement measure & $\begin{array}{l}\text { Abatement rate, } \\
\text { tCO2eq ha }{ }^{-1} \mathrm{yr}^{-1}\end{array}$ & Cost-effectiveness, EUR tCO2eq ${ }^{-1}$ & Source & Location \\
\hline $\begin{array}{l}\text { Precision nutrient } \\
\text { application }\end{array}$ & $15-34 \%$ & $\begin{array}{l}0-39 \text { for farms } 400 \text { ha } \\
6-332 \text { for farms } 100-200 \text { ha }\end{array}$ & ICF (2013) & USA \\
\hline Leguminous crops & 1.02 & 18-19 & Pellerin et al. (2013) & France \\
\hline \multirow[t]{4}{*}{ Cover crops } & $0.874+/-0.393$ & 160 & Pellerin et al. (2013) & France \\
\hline & 1.0 & 50 & Schulte et al. (2012) & Ireland \\
\hline & 1.75 & 178 & Posthumus et al. (2013) & UK \\
\hline & 0.88 & 124 & McVittie et al. (2014) & Denmark \\
\hline \multirow{2}{*}{$\begin{array}{l}\text { Minimum tillage - } \\
\text { Winter wheat }\end{array}$} & 0.15 & -56 & McVittie et al. (2014) & Denmark \\
\hline & 0.15 & -117 & McVittie et al. (2014) & Scotland \\
\hline No-till - Winter wheat & 0.70 & 165 & McVittie et al. (2014) & Scotland \\
\hline \multirow[t]{2}{*}{ Nitrification inhibitors } & 0.3 & $107-202$ & Moran et al. (2008) & UK \\
\hline & & 61 & Pellerin et al. (2013) & France \\
\hline Residue (straw) & 2.29 & 125 & McVittie et al. (2014) & Scotland \\
\hline $\begin{array}{l}\text { management - } \\
\text { Winter wheat }\end{array}$ & 2.29 & 48 & McVittie et al. (2014) & Denmark \\
\hline
\end{tabular}




\section{AGRICULTURAL AND FOOD SCIENCE}

J. Lankoski et al. (2020) 29: 110-129

\section{Environmental co-impacts of GHG abatement measures}

Most of the GHG mitigation measures have environmental co-impacts, in most cases co-benefits but in some cases tradeoffs with negative impacts. For example, cover crops improve water quality via reduced nutrient runoff (Schulte et al. 2012, Kirk et al. 2012, Wiltshire et al. 2014). Precision nutrient application contributes to improved water quality by increasing nutrient use efficiency and thus reducing nutrient surpluses and potential nutrient leaching and runoff. The use of nitrification inhibitors contributes to reduced nitrogen leaching and thus improved water quality (Schulte et al. 2012). Leguminous crops contribute to improved water quality through reduced leaching of nitrate (Nemecek et al. 2008) and may also have a positive impact on biodiversity (Legume Futures 2014, Bues et al. 2013). The adoption of no-till and reduced/minimum tillage usually reduces soil erosion, nitrogen runoff, and particulate phosphorus runoff, but it may increase dissolved phosphorus runoff and herbicide runoff (Lankoski et al. 2006). Conversion of cropland to perennial grasses to sequester soil carbon may improve wildlife habitats and water quality.

Greenhalgh and Sauer (2003) and Pattanayak et al. (2004) both find that the water quality benefit of carbon sequestration practices is very significant. Pattanayak et al. (2004) analyze the water quality co-benefits of GHG mitigation practices by linking a national-level water quality model to a national-level agriculture sector model. Payments of USD 25 and USD $50 \mathrm{tCO}_{2} \mathrm{eq}^{-1}$ induce the conversion of agricultural land into forestland, changes in tillage practices and crop mixes on remaining agricultural land, and changes in livestock management. These responses will mitigate $60-70$ million $\mathrm{tCO}_{2}$ eq and improve aggregate national water quality by $2 \%$. Moreover, these practices will reduce annual nitrogen loadings into the Gulf of Mexico by up to half of the reduction goals established by the national Watershed Nutrient Task Force for addressing the hypoxia problem (Pattanayak et al. 2004). McCarl and Schneider (2001) found that an increase in carbon prices will reduce sediment, nitrogen and phosphorus runoff.

Feng et al. (2007) used the Environmental Policy Integrated Climate (EPIC) model to assess carbon sequestration, erosion reduction, and nutrient runoff reduction benefits of different targeting mechanisms of Conservation Reserve Program (CRP) funds in the Upper Mississippi River Basin. For the whole area, the annual average rate of carbon sequestration of adopting CRP practices was 0.487 tons per acre. Their analysis shows that if the CRP had been targeted at carbon specifically, carbon sequestration benefits would have been four times larger, erosion reduction $69 \%$ lower, and nitrogen runoff reduction $26 \%$ higher than in the case of the actual CRP allocation. If the CRP had been targeted at erosion specifically, almost three times more erosion benefit would have been achieved. Their analysis also shows that different regions benefit from the program depending on which environmental issue is targeted.

Feng et al. (2007) assessed the co-benefits from carbon sequestration policy in a large agricultural region in the U.S. and found that the co-benefits are likely to be sizable in absolute magnitude, highly variable across subregions, and dependent on policy design. Thus, if society values these co-benefits, a carbon market or carbon sequestration policy that does not address these co-benefits will not maximize social welfare. Hence, policy design issues related to co-benefits are important for the efficient design of GHG mitigation policies in the agriculture sector.

\section{Policy instruments promoting mitigation in agriculture}

In contrast to studies on technical mitigation measures, the literature on policy instruments targeting GHG emissions is scarce (Bakam et al. 2012, De Cara et al. 2005, Pérez Domínguez and Britz 2003). Nevertheless, it has focused on multiple instruments targeting either livestock production or crop production. Some of the literature develops a full Pigouvian set of policy instruments addressing both climate and water quality damage (Lötjönen et al. 2020, Ervola et al. 2018). Most of the literature focuses solely on GHG emissions and policy instruments addressing GHG emissions or emission drivers such as fertilizer inputs and ruminant heads. Very few of the studies also consider transaction costs related to different policy instruments (notable exceptions are Pérez Domínguez and Britz 2003, Bakam et al. 2012, De Cara et al. 2018, Ervola et al. 2018, OECD 2019).

As shown above, the possible options to reduce GHG emissions from livestock are rather limited, and most impacts can be obtained from mixed crop-dairy farms via cultivation choices. Nevertheless, the literature (see, e.g., Lengers and Britz 2012, OECD 2019, Lötjönen et al. 2020) has identified at least four policy instruments that can target emissions from livestock production. They are a GHG tax - or abatement subsidy or emissions trading levied on actual or estimated emissions, an animal (ruminant) tax, regulatory requirements on manure storage, 


\section{AGRICULTURAL AND FOOD SCIENCE}

J. Lankoski et al. (2020) 29: 110-129

and subsidies for a low GHG emission diet for ruminants. Furthermore, there always exists a possibility of reducing meat consumption through a meat tax (see, e.g., Wirsenius et al. 2011, Säll and Gren 2015). Although this instrument targets agriculture only indirectly, we briefly comment on it as well.

Regarding crop production, the most often examined instruments are a GHG tax, an abatement subsidy, GHG emissions trading and input taxes (e.g., Ervola et al. 2018, OECD 2019, Bakam et al. 2010). In addition, new policy instruments have been developed to promote farmers' adoption of soil carbon sequestration practices, which provide positive externalities for society. Government payments for soil carbon sequestration or farmers' voluntary participation in carbon offset markets serve as examples of these mitigation policy instruments (e.g., Gonzales-Ramirez et al. 2012).

\section{GHG emission tax, GHG abatement subsidy and GHG emissions trading}

A GHG tax (carbon tax) and emissions trading impose a price on GHG emissions, while a GHG abatement subsidy provides a reward for a unit of abatement - also providing an efficient price for emissions. Recall equation (7), where the carbon tax $t$ (also interpreted as an emission allowance price) replaces the climate damage function $d$. Thus, the carbon price enters the private optimality conditions (2a) - (6a) and adjusts all choices of the private farmers towards the social optimum. Under a uniform carbon price, all farmers face the same price for emissions, and they adjust their use of inputs and land allocation to reduce emissions in a way that equalizes their marginal abatement costs, which is a requirement for minimizing the economic cost of abatement.

An abatement subsidy works similarly at the margin, but unlike the emission tax, the subsidy increases private profits. This becomes visible once we rewrite the private profit function (equation 7 ) in terms of the subsidy. Let $\beta$ denote the uniform subsidy rate and $, z_{j}, j=H, s, c$ denote the GHG emission baselines from cows, silage and crops, respectively, reflecting private choice before climate policy is introduced.

$$
\pi=\left[\Omega H+\beta\left(z_{H}-E H\right)-i(H)\right]+\left[\Pi^{s}+\beta\left(z_{s}-e^{s}\right)+\Pi^{c}+\beta\left(z_{c}-e^{c}\right)\right]
$$

When choosing herd size, diet, fertilization and land allocation, a farmer would face similar optimality conditions as under the GHG tax. However, now, the difference between the baseline and the new emissions would bring revenue and counteract the reduction in profitability and possibly incentivize the entry of new farmers or more land use to agriculture sector. Therefore, a GHG tax and GHG abatement subsidies differ with respect to total GHG emissions, farm profits, and government budgets.

The quantitative impacts of these policy instruments can be examined in either partial or general equilibrium frameworks. Lengers and Britz (2012) and Lötjönen et al. (2020) provide examples of partial analysis of carbon instruments at the farm level. Lengers and Britz analyze mitigation measures with a detailed biodynamic DAIRYDYN model and recommend indicators as a basis for climate policies instead of actual emissions. Lötjönen et al. (2020) in turn use a farm model and recommend levying carbon tax on either all or the main emission sources.

OECD (2019) employs a general equilibrium analysis to investigate the performance of the above market-based instruments in agriculture at the global level. This work is based on the Modular Applied GeNeral Equilibrium Tool (MAGNET), which is a multisector, multiregion computable general equilibrium model that covers the global economy. The analysis reveals that the mitigation effectiveness of the global abatement subsidy is only half of the emissions reductions of the global GHG tax. The reason is that the cost and price increases from the tax cause a contraction in the supply of and demand for agricultural products in aggregate, particularly for GHG emissionsintensive products. The two instruments also differ with respect to their impact on agricultural income, competitiveness, food consumption and government budgets. Although a global GHG tax is more effective in mitigation, global abatement subsidies provide considerable emission reductions without causing economic losses to agricultural producers or food consumers, which reduces the potential political and social barriers to implementing this policy option (OECD 2019).

The cost-effectiveness of these instruments has been examined in many studies. OECD (2019) provides a farmlevel analysis for selected EU countries. It shows that all three policy instruments provide exactly the same marginal incentives for emission reduction and result in the same marginal abatement costs (EUR $50.2 \mathrm{tCO}_{2} \mathrm{eq}^{-1}$ ) at the $10 \%$ emission reduction level when transaction costs are not considered. Including transaction costs improves the relative performance of the GHG tax and abatement subsidy over GHG emissions trading. A comparison of emissions trading with uniform emission constraints shows, on average, $17 \%$ cost-effectiveness gains for emissions trading. 
Pérez Domínguez and Britz (2003) find similar gains (23\%) from emissions trading relative to uniform emissions constraints for the EU27. De Cara et al. (2005) compare the GHG emissions tax with uniform emission constraints and show that meeting an $8 \%$ GHG abatement target is more than twice as expensive under the uniform emission constraint as it is under the emission tax. Bakam et al. (2012) obtain similar results for GHG emission trading over an input tax for GHG emission reduction targets over $29 \%$.

The results from these studies suggest that market-based instruments provide the most cost-effective options for GHG mitigation in agriculture. They also indicate that it pays to target GHG emissions broadly, just as equations (6) and (7) demonstrate. There are two reservations that may weaken the feasibility of these results. First, a broad tax base requires the authorities to be able to efficiently monitor the actual choices within farms. OECD (2019) finds that every euro spent on better monitoring, reporting and verification, which increases transaction costs, brings EUR 1.3 through improved cost-effectiveness. How to improve monitoring and how costly it actually is, however, is a highly debatable issue. The second issue concerns the abatement subsidy. It has a high cost impact on the government's budget, unlike the emission tax, which increases budget revenue. This feature decreases the desirability of the subsidy unless the government only shifts some of the existing farm income support to the abatement subsidy outlays in a budget-neutral manner (we will discuss this later).

\section{Input taxes: ruminant tax and fertilizer tax}

An animal tax (ruminant tax) refers to a tax that is levied on the productive animal. The motivation for the tax is as follows. The main source of GHG emissions from dairy and cattle farming is enteric fermentation. Given that the privately optimal herd size is always higher than the socially optimal one (as shown in equations $2 a$ and 2b), reducing the number of heads is the quickest and most certain way of reducing GHG emissions. Moreover, taxing emission-intensive inputs (ruminant animals or nitrogen fertilizer) circumvents the substantial challenge of measuring and monitoring all emissions from mixed dairy-crop farms, which is the case for GHG emissions taxes that address all emissions from farms. Taxing emission-intensive inputs instead of emissions allows some savings on transaction costs related to measurement and monitoring. The drawback is that resorting to the second-best taxation reduces economic efficiency since it fails to incentivize the adoption of mitigation practices that reduce the emission intensity of production. Drawing on this line of thinking, it has been suggested that a tax on the number of animals (ruminant heads) may be the most easily implemented climate instrument for dairy and cattle livestock farming (see, e.g., OECD 2019).

The animal tax rate may reflect the average emissions from enteric fermentation with a certain feeding regime per year multiplied by climate damage (see, e.g., Lötjönen et al. 2020), or alternatively, it can additionally reflect emissions from manure storage and application. Equation (9) demonstrates how the ruminant tax (denoted by $\tau$ ) enters a private farmer's profit function,

$$
\pi=[\Omega H-\tau E H-i(H)]+\left[\Pi^{s}+\Pi^{c}\right]
$$

Thus, the ruminant tax is levied on the emissions from animals. In the absence of means to reduce per animal GHG emissions, this tax is simply a unit tax on ruminant animals. The only way a farmer may respond to the tax is to reduce the number of animals. A reduction in the number of animals, however, also has effects on fertilization and land allocation. The reduced amount of manure increases the use of mineral fertilizer and reduces the amount of land allocated to silage - both changes tend to increase GHG emissions. If the farmer could adjust diet or manure storage and application technologies to reduce emissions, the tax burden could be reduced. However, due to measurement and monitoring problems, the most realistic option to implement a ruminant tax is a constant uniform tax based on the average type of feeding regime and manure management.

No country has implemented a ruminant tax, which is perceived as a very strong instrument. However, there are simulations examining the implications of a ruminant tax. OECD (2019) suggests that a global GHG tax leads to a much larger emissions reduction than a global tax on ruminants, $1595 \mathrm{MtCO}_{2}$ eq by 2050 , while for a ruminant tax, the emission reduction is $301 \mathrm{MtCO}_{2}$ eq by 2050. Lötjönen et al. (2020) provide a farm-level analysis and find that the ruminant tax leads to an approximately $24 \%$ lower reduction in emissions relative to a general GHG tax on a mixed crop-dairy farm. A farm-level analysis by OECD (2019) shows that the cost-effectiveness of a ruminant tax is relatively good: EUR $50.2 \mathrm{tCO}_{2} \mathrm{eq}^{-1}$ for an emission tax and EUR $53.6 \mathrm{tCO}_{2} \mathrm{eq}^{-1}$ for a ruminant tax. Although transaction costs improve the relative performance of a ruminant tax, an emission tax is still the most cost-effective policy instrument (with transaction costs EUR $53.7 \mathrm{tCO}_{2} \mathrm{eq}^{-1}$ for an emission tax and EUR $55.6 \mathrm{tCO}_{2} \mathrm{eq}^{-1}$ for a ruminant tax). 


\section{AGRICULTURAL AND FOOD SCIENCE}

J. Lankoski et al. (2020) 29: 110-129

The introduction of a national ruminant tax may lead to carbon leakage, challenging the adoption of a unilateral national tax policy. An alternative is to focus on consumers. Increased information on healthy diets could decrease the demand for meat (see, e.g., Rickertsen et al. 2003). The literature has also suggested using another instrument to target ruminants: a meat tax levied on consumers instead of producers (Wirsenius et al. 2011). In the EU, Wirsenius et al. (2011) found that a tax of EUR 60 tCO 2 eq on animal food products would reduce GHG emissions by 32 million tons (with the main effect stemming from ruminant meat). Drawbacks of the meat tax include reduced profits from the products and the lack of incentives it provides producers to reduce GHG emissions within the production stage (Wirsenius et al. 2011).

We next turn to another input tax, a tax on nitrogen fertilizers, as a means of reducing GHG emissions. The motivation for a nitrogen tax as a climate instrument is as follows. The manufacture of mineral fertilizers causes GHG emissions, and mineral nitrogen is a source of $\mathrm{N}_{2} \mathrm{O}$ emissions from soils. When a nitrogen tax $(t)$ is used, the private farmer's profit function is

$$
\pi=[\Omega H-i(H)]+\left[\Pi^{s}(t)+\Pi^{c}(t)\right] .
$$

Equation (10) shows that the nitrogen tax impacts the profits from crop production (silage and crops). A look at the first-order conditions in equations (5b) and (6b) helps to reveal the two main impacts of the tax. By equation (5b), the tax increases its RHS, implying an increase in the use of manure. Equation (6b) in turn shows that the RHS profits decrease and more land is allocated to silage due to its improved profitability. Unfortunately, in a mixed dairy-crop production farm, the size of the herd may even increase, tending to increase methane emissions. This is, again, an indication of how complicated climate policy in agriculture can be.

Ervola et al. (2018) employ data from Finland and focus on water quality and GHG emissions damage from crop production. Their analysis simultaneously includes a socially optimal fertilizer tax, a soil emissions tax and a subsidy for soil carbon sequestration (for green set-aside and afforestation). Simulations for Finnish agriculture show that the optimal fertilizer tax rate is uniform (19\%) when GHG emission damage is internalized (but is differentiated when water quality damage is accounted for). The optimal fertilizer taxes vary from $19 \%$ to $58 \%$ and depend on soil type (mineral, clay or organic soil), soil productivity and tillage method (conventional moldboard plow tillage or no-till). The optimal tax on soil emissions varies from EUR $15 \mathrm{ha}^{-1}$ in clay soils to EUR $231 \mathrm{ha}^{-1}$ in organic soils. Different policy scenarios (water quality policy, climate policy, or combined water quality and climate policy) have differential fiscal effects.

\section{Voluntary carbon contracts and offset mechanisms}

Recent initiatives towards carbon farming offer new directions for policy development. Carbon farming refers to farming practices that increase the carbon content in soils, mostly via photosynthesis. France's initiative aimed at sequestering 4\%o annually in soils has spurred carbon farming (Minasny et al. 2017). Carbon offset programs have played a part in GHG policies in the international arena, but recently, the question has become whether farmers could benefit nationally from carbon farming beyond increased agricultural productivity, as sequestering carbon in soil reduces $\mathrm{CO}_{2}$ content in the atmosphere, providing a positive climate externality. There are alternative ways of promoting carbon farming: either using the abovementioned carbon tax-subsidy combination (Ervola et al. 2018) or relying on voluntary mechanisms, such as carbon contracts and offsets (Lewandrovski et al. 2004, Antle et al. 2007, Gonzalez-Ramirez et al. 2012).

Carbon offsetting is a market mechanism in which companies buy carbon offsets (credits) from agriculture to compensate for their emissions. For them to be sustainable from a climate perspective, the literature emphasizes that carbon offsets must fulfill the requirements of strict additionality, permanence and verifiability. Governments must provide a sound basis for offsetting (Gonzalez-Ramirez et al. 2012). Niles et al. (2019) propose an umbrella protocol to ease the application of offset schemes across regions, crops, and practices. Traditionally, offset protocol development has involved creating a new protocol for each combination of practice, crop and region, which is time consuming. The protocol development and approval process can be accelerated through the development of an umbrella protocol that encompasses one particular type of GHG or management practice, which can then be expanded to different crops, regions and practices. Such protocols are expected to reduce workload and time for policy development.

Most of the studies that have analyzed soil carbon sequestration show that some sequestration is economically feasible at a relatively low C price, i.e., in the range of USD $10 \mathrm{tC}^{-1}$, but the rate of participation in $\mathrm{C}$ contracts 
responds significantly to the $C$ price. However, at low $C$ prices, the amount of soil $C$ that is sequestered is far below the technical potential, and the technical potential is approached only at prices in the range of USD 100 to USD $200 \mathrm{tC}^{-1}$. These studies also show that the technical potential and economic feasibility of carbon sequestration vary substantially by region and type of practice (Lewandrovski et al. 2004, Antle et al. 2007).

Lewandrovski et al. (2004) analyzed the performance of alternative incentive designs and payment levels if farmers were paid to adopt land use and management practices that raise soil carbon levels. At payment levels below USD 10 per ton for permanently sequestered carbon, their analysis suggests that farmers would adopt changes in rotation and tillage practices, while at higher payment levels, afforestation dominates. Their analysis shows that the most cost-effective payment design adjusts payment levels to account both for the length of the contract and for the net sequestration.

Manley et al. (2005) studied offsets from no-till practices in the US with two meta-analyses. They found that the cost-effectiveness of no-till in increasing carbon accumulation in soil varies heavily with, for example, region, crop and soil carbon measurement depth. Efforts to use no-till to produce carbon offset credits should thus target farmland where a switch from conventional tillage to no-till provides net sequestration at relatively low cost.

The most typical approaches for designing voluntary carbon contracts are per-ton (or per-hectare) contracts, output-based-offset (OBO) contracts, a principal-agent-contract approach, and a dynamic abatement cost model approach (Gonzalez-Ramirez et al. 2012). Antle et al. (2003) examined the per-ton and per-hectare contracts for soil $C$ sequestration. The per-hectare contract provides incentive payments to producers for each hectare of land that is switched from a production system associated with a relatively low equilibrium level of soil $\mathrm{C}$ to a system associated with a higher equilibrium level of soil $C$. The key feature of the per-hectare contract is that the payment per hectare is the same for all land under the contract that uses a specified technology, regardless of the amount of $\mathrm{C}$ that is actually sequestered as a result. The per-ton contract pays farmers a specified price for each ton of $\mathrm{C}$ that is accumulated and maintained in the soil for the duration of the contract, regardless of what management practices are used.

To implement per-ton contracts, it is necessary to quantify the amount of $\mathrm{C}$ added to the soil over the duration of the contract; hence, it is necessary to establish the baseline amount of $C$ in the soil at the beginning of the contract and the time path of soil $\mathrm{C}$ over the duration of the contract. In their analysis of the marginal cost of soil C sequestration, Antle et al. (2003) find that a per-hectare payment scheme is as much as four times more costly than the per-ton payment mechanism, and this inefficiency loss is much larger than the transaction costs of implementing the more efficient contract.

Murray and Baker (2011) focus on an output-based offset contract, which is based on a baseline for crop yields and GHG emissions. The output-based offset approach establishes projected emissions and yields and establishes the baseline emission intensity, defined as a ratio between the projected GHG emissions and the projected yields. When signing the contract, a farmer agrees to reduce emissions intensity. Given the ratio, the farmer can attain a reduction either by reducing net emissions or by increasing yields. Credits are calculated as the product of the actual yield and the realized difference in the emission intensities.

Technically more complicated approaches by Mason and Plantinga (2011) and Fell et al. (2010) are more general and less rooted in agriculture. Mason and Plantinga (2011) propose a principal-agent framework for carbon offset contracts to ensure that policy makers do not pay for farmers who would supply carbon offsets even without the payment; thus, the aim is to ensure true additionality of contracts. Fell et al. (2010) suggest the use of a dynamic stochastic abatement cost model for the offset market.

\section{Other policy options}

Regulation of manure management

Manure-related GHG emissions can be reduced slightly by employing the right technological choices. A form of direct regulation would be to require the use of covered manure storage. Increasing importance can be given to the regulation of nutrients in manure. Nutrient separation, that is, separation of manure into phosphorus- and nitrogen-dominant fractions using technological solutions, in livestock farms focuses more on water quality policies than climate policies (see Ollikainen et al. 2019 for a more general discussion). It has a connection to climate policies via biogas production, as discussed below. 


\section{AGRICULTURAL AND FOOD SCIENCE}

J. Lankoski et al. (2020) 29: 110-129

Support for biogas production

Using manure and biomass, such as grass, in a fermentation process produces biogas that can be used to replace fossil fuels either in transport or electricity production. The key issue economically is what type of subsidy works best. A well-known tradeoff exists between investment support and production support. Investment subsidies may induce investment, but production may turn out to be unprofitable. Production subsidies in turn may help plants that have received investment but may not trigger investments. Very much depends on technological development and local conditions but perhaps even more on carbon prices in energy production and transport. Additional issues in biogas production relate to the possible requirement that nutrients be separated after biogas production. This regulatory instrument stems more from water quality policies. The instrument combination of biogas subsidies and nutrient separation requirements appears ideal from an environmental point of view. Economically, this policy would increase the costs of biogas production on the one hand but provide possibilities to sell manure nutrients to crop production farms on the other hand. Biogas production is promoted in some countries, such as Denmark and Finland. The typical instrument has been an investment subsidy.

\section{Subsidy for fat supplementation in livestock diet}

Subsidizing fat supplements in livestock diets is an interesting theoretical option. Society could subsidize using oil as a part of the diet to reduce $\mathrm{CH}_{4}$ emissions from enteric fermentation (Bates et al. 2009, MacLeod et al. 2015). While studies of economic incentives on this subject are lacking, we must, however, note that this instrument is subject to moral hazard; livestock farmers might take the subsidy but not use the costly oil in the diet, as authorities have no means to monitor the actual choice of the diet. Thus, an alternative would be a regulation relating to manufacturers of concentrate feeds to increase oil supplementation in all products. Whether the cost increase should be compensated to farmers, would be up to national decisions. Theoretically, there is no obligation for compensation, as the measure reduces negative externalities.

\section{Re-instrumentation of agricultural support policies}

Agricultural support policies, such as market price supports, payments based on output, and payments based on inputs, increase the use of inputs, shift land towards the supported crops and increase the entry of land into the agriculture sector. The overall effect is an increase in GHG emissions from the agriculture sector relative to a case in which no support measures are provided, as shown by Henderson and Lankoski (2019) for a number of countries. They also demonstrate that fully decoupled support payments do not increase GHG emissions from the sector. Regarding climate mitigation policy, their results suggest as a necessary first step reforming agricultural support policies: reduce and eventually remove those support policies that increase GHG emissions (remove the policy failure) before implementing specific mitigation policies to address remaining emissions (addressing the environmental market failure).

\section{Barriers to the implementation of climate policies}

Aside from social acceptability, the greatest potential barriers to ambitious climate policy in agriculture relate to the measurement, reporting and verification (MRV) of GHG emissions reductions. Given that the agriculture sector consists of a large number of heterogeneous (in terms of both productivity and environmental sensitivity) production units with mostly nonpoint source types of emission sources, the MRV challenges are remarkable and imply high transaction costs. Furthermore, some emissions sources and sinks, such as $\mathrm{N}_{2} \mathrm{O}$ emissions from soil or soil carbon sequestration, are likely to be more uncertain and difficult to measure, which results in stronger tradeoffs between transaction costs and MRV accuracy (Grosjean et al. 2016).

However, given that a high share of MRV-related costs are fixed costs, which are invariant to farm size, it may be possible to decrease these costs by aggregating farms into larger units for MRV purposes (Bellassen et al. 2015, OECD 2019). Additionally, the existing institutional capacity created for other policies (e.g., EU Common Agricultural Policy (CAP) or EU environmental directives) can reduce the costs of MRV since various MRV tools may already exist (Grosjean et al. 2016). 


\section{AGRICULTURAL AND FOOD SCIENCE}

J. Lankoski et al. (2020) 29: 110-129

\section{Conclusions}

Climate policy is more relevant to the agriculture sector than before. There is a need to identify the best available GHG abatement measures and develop new ones. Even more important is to design effective incentives for reducing GHG emissions from agriculture in a way that also promotes new and innovative solutions. We now briefly discuss both aspects.

For the most polluting part of agriculture, ruminant livestock production, the reviewed estimates show high abatement costs for most measures, many exceeding by 10 times the allowance prices in the EU ETS (where the average price in 2019 was slightly over EUR 20 ton $^{-1}$ ). In contrast, abatement costs are much lower (sometimes even negative) in crop production. This indicates that with the exception of GHG emissions from enteric fermentation, agriculture has many measures to reduce GHG emissions. The relevant policy questions are as follows: what is the willingness of governments to require emissions reductions in agriculture, and how can emissions reductions be efficiently achieved?

Answering the first question is beyond the scope of this study, but our review provides answers to the second question. First, market-based instruments, levied on all sources of GHG emissions, perform best according to simulations. Second, accounting for the heterogeneity and challenges in monitoring may be avoided by employing process-based models to estimate emissions with a given type of feeding regime, manure management technology, soil type, tillage method and other main aspects. Third, if heterogeneity presents an unsolvable problem, emission proxies, such as default emission factors for ruminant animals, can be used instead of directly measuring emissions, but their effectiveness is clearly lower than that of emissions-based policies. Fourth, a first step towards more effective climate policies is to reform the current agricultural support policies by decoupling support from production decisions.

Our review produces some interesting findings concerning the state of the art in the research relating to climate policy. Current data on emission reductions from alternative measures exhibit a wide range, creating uncertainty on the performance of measures. The source of these differences lies partly in the chosen approaches (measurement on site versus various modeling possibilities) and partly in vastly heterogeneous production conditions and site productivity of soil carbon sequestration. We definitely need a better, consistent data basis for climate policy design and implementation. Second, the choice of model matters considerably for the simulation results of alternative GHG policy instruments. Farm models provide information on farmers' choices under the chosen behavioral assumptions. However, by keeping prices unchanged, they promise much stronger reductions in GHG emissions than partial equilibrium (sector) and general equilibrium models, which let prices vary, creating interactions between livestock and crop production lines. Sharpening the analysis with the help of econometric and other studies focusing on actual behavior is hardly feasible, as no country has implemented strong, ambitious climate policy in the agriculture sector. Finally, innovations seem to play a minor role in the current literature, even though there is an enormous need for them.

There is no doubt that agriculture needs innovations. Globally, the most challenging area of agriculture relates to animal production, which is a significant source of methane emissions, and globally, $26 \%$ of the ice-free land area is used for livestock grazing, while an additional one-third of cropland is used to produce feed for livestock (FAO 2012). Therefore, the direction of innovation should be towards a lower amount of required livestock herds and the release of land back to nature and to biodiversity maintenance. Restricting the analysis solely within traditional agriculture as a source of food is no longer sufficient. The new developments relating to the use of synthetic biology and renewable energy producing proteins from microbes in industrial plants may be crucial both in producing enough food for the increasing population and in reducing GHG emissions (e.g., Post 2012). Innovation policy for climate purposes is needed for both the food industry and primary agriculture, for instance, animal breeding to increase productivity that allows a decrease in herd sizes.

\section{Acknowledgments}

This work is a part of research consortium "Multi-benefit solutions to climate-smart agriculture" (MULTA), funded by the Strategic Research Council of Academy of Finland (Contract No. 327342). We thank three anonymous reviewers for their helpful comments. The opinions expressed and arguments employed herein are solely those of the authors and do not necessarily reflect the official views of the OECD or of its member countries. 


\section{References}

Antle, J.M., Capalbo, S.M., Mooney, S., Elliott, E.T. \& Paustian, K.H. 2003. Spatial Heterogeneity, Contract Design, and the Efficiency of C Sequestration Policies for Agriculture. Journal of Environmental Economics and Management 46: 231-250. https://doi.org/10.1016/S0095-0696(02)00038-4

Antle, J.M., Capalbo, S.M., Paustian, K.H. \& Ali, M.K. 2007. Estimating the Economic Potential for Agricultural Soil C Sequestration in the Central United States Using an Aggregate Econometric-Process Simulation Model. Climatic Change 80:145-171. https://doi.org/10.1007/s10584-006-9176-5

Bakam, l., Balana, B. \& Matthews, R. 2012. Cost-effectiveness analysis of policy instruments for greenhouse gas emission mitigation in the agricultural sector. Journal of Environmental Management 112: 33-44. https://doi.org/10.1016/j.jenvman.2012.07.001

Bates, J., Brophy, N., Harfoot, M. \& Webb, J. 2009. Agriculture: methane and nitrous oxide. In: Sectoral Emission Reduction Potentials and Economic Costs for Climate Change (SERPEC-CC), Ecofys, AEA Energy and Environment, Didcot, UK.

Bellassen, V., Stephan, N., Afriat, M., Alberola, E., Barker, A., Chang, J.P., Chiquet, C., Cochran, I., Deheza, M., Dimopoulos, C. \& Foucherot, C. 2015. Monitoring, reporting and verifying emissions in the climate economy. Nature Climate Change 5: 319-328. http://dx.doi.org/10.1038/nclimate2544.

Bennetzen, E., Smith, P. \& Porter, J. 2016. Agricultural production and greenhouse gas emissions from world regions-The major trends over 40 years. Global Environmental Change 37: 43-55. https://doi.org/10.1016/j.gloenvcha.2015.12.004

Blandford, D. \& Hassapoyannes, K. 2018. The role of agriculture in global GHG mitigation. OECD Food, Agriculture and Fisheries Papers, No. 112, OECD Publishing, Paris. https://doi.org/10.1787/da017ae2-en

Bues, A., Preissel, S., Reckling, M., Zander, P., Kuhlman, T., Topp, K., Watson, C., Lindström, K., Stoddard, F.L. \& Murphy-Bokern, D. 2013. The environmental role of protein crops in the new common agricultural policy. The European Parliament, Brussels. http:// www.europarl.europa.eu/delegations/en/studiesdownload.html?languageDocument=EN\&file=93370

Chen, X.H., Zhou, L.X., Zhao, Y.G., Pan, S.D. \& Jin, M.C. 2014. Application of nanoring amino-functionalized magnetic polymer dispersive micro-solid-phase extraction and ultra fast liquid chromatography-tandem mass spectrometry in dicyandiamide residue analysis of powdered milk. Talanta 119:187-192. https://doi.org/10.1016/j.talanta.2013.10.003

De Cara, S., Houzé, M. \& Jayet P. 2005. Methane and Nitrous Oxide Emissions from Agriculture in the EU: A Spatial Assessment of Sources and Abatement Costs. Environmental and Resource Economics 32: 551-583. https://doi.org/10.1007/s10640-005-0071-8

De Cara, S., Henry, L. \& Jayet, P. 2018. Optimal coverage of an emission tax in the presence of monitoring, reporting, and verification costs. Journal of Environmental Economics and Management 89: 71-93. http://dx.doi.org/10.1016/j.jeem.2018.03.001.

Dequiedt, B. \& Moran, D. 2015. The cost of emission mitigation by legume crops in French agriculture. Ecological Economics 110 : 51-60. https://doi.org/10.1016/j.ecolecon.2014.12.006

Duncan, E.W., Dell, C.J., Kleinman, P.J.A. \& Beegle, D.B. 2017. Nitrous oxide and ammonia emissions from injected and broadcast-applied dairy slurry. Journal of Environmental Quality 46: 36-44. https://doi.org/10.2134/jeq2016.05.0171

Eory, V., Pellerin, S., Garcia, G.C., Lehtonen, H., Licite, I., Mattila, H., Lund-Sørensen, T., Muldowney, J., Popluga, D., Strandmark, L. \& Schulte, R. 2018. Marginal abatement cost curves for agricultural climate policy: state-of-the art, lessons learnt and future potential. Journal of Cleaner Production 182: 705-716. https://doi.org/10.1016/j.jclepro.2018.01.252

Ervola, A., Lankoski, J., Ollikainen, M. \& Mikkola, H.J. 2012. Agriculture and climate change: The socially optimal production, land use, and GHG emissions. Food Economics 9: 10-24.https://doi.org/10.1080/16507541.2012.695120

Ervola A., Lankoski, J. \& Ollikainen, M. 2018. Climate and Water Quality Policy Design for Agriculture with Environmental CoBenefits. Modern Concepts \& Developments in Agronomy 3: 1-17. https://doi.org/10.31031/MCDA.2018.03.000552

FAO 2012. Livestock and landscapes. Sustainability pathways. http://www.fao.org/3/ar591e/ar591e.pdf. Accessed 23 March 2020.

Fell, H., Burtraw, D., Morgenstern, R. \& Palmer, K. 2010. Climate policy design with correlated uncertainties in offset supply and abatement costs, Discuss. Pap. DP-10-01 Resources for the Future, Washington DC. https://doi.org/10.2139/ssrn.1552176

Feng, H., Kurkalova, L.A., Kling, C.L. \& Gassman, P.W. 2007. Transfers and environmental co- benefits of carbon sequestration in agricultural soils: retiring agricultural land in the Upper Mississippi River Basin. Climatic Change 80: 91-107. https://doi.org/10.1007/s10584-006-9143-1

Frank, S., Beach, R., Havlík, P., Valin, H., Herrero, M., Mosnier, A., Hasegawa, T., Creason, J., Ragnauth, S. \& Obersteiner, M 2018. Structural change as a key component for agricultural non-CO2 mitigation efforts. Nature Communications 9: 1-8. https://doi.org/10.1038/s41467-018-03489-1

Gerber, P.J., Steinfeld, H., Henderson, B., Mottet, A., Opio, C., Dijkman, J., Falcucci, A. \& Tempio, G. 2013. Tackling climate change through livestock: a global assessment of emissions and mitigation opportunities. Food and Agriculture Organization of the United Nations (FAO), Rome.

Golub, A., Hertel, T., Lee, H.L., Rose, S. \& Sohngen, B. 2009. The opportunity cost of land use and the global potential for greenhouse gas mitigation in agriculture and forestry. Resource and Energy Economics 31: 299-319. http://dx.doi.org/10.1016/j.reseneeco.2009.04.007.

Gonzales-Ramirez, J., Kling, C. \& Valcu, A. 2012. An Overview of Carbon Offsets from Agriculture. Annual Review of Resource Economics 4: 45-84. https://doi.org/10.1146/annurev-resource-083110-120016

Greenhalgh, S. \& Sauer, A. 2003. Awakening the Dead Zone: An Investment for Agriculture, Water Quality and Climate Change. Issue Brief, World Resources Institute.

Grosjean, G., Fuss, S., Koch, N., Bodirsky, B.L., De Cara, S. \& Acworth, W. 2016. Options to overcome the barriers to pricing European agricultural emissions. Climate Policy 18: 151-169. https://doi.org/10.1080/14693062.2016.1258630 
Grönroos, J. 2014. Maatalouden ammoniakkipäästöjen vähentämismahdollisuudet ja -kustannukset. Reports of the Ministry of the Environment 26. (in Finnish).

Havlik P., Valin, H., Herrero, M., Obersteiner, M., Schmid, E., Rufino, M.C., Mosnier, A., Thornton, P.K., Bottcher, H., Conant, R.T., Frank, S., Fritz., S., Fuss, S., Kraxner, F. \& Notenbaert, A. 2014. Climate change mitigation through livestock system transitions. Proceedings of the National Academy of Sciences of the United States of America 111: 3709-3714. https://doi.org/10.1073/pnas.1308044111

Heikkinen, J., Ketoja, E., Nuutinen, V. \& Regina, K. 2013. Declining trend of carbon in Finnish cropland soils in 1974-2009. Global Change Biology 19: 1456-1469. https://doi.org/10.1111/gcb.12137

Henderson, B. \& Lankoski, J. 2019. Evaluating the environmental impact of agricultural policies. OECD Food, Agriculture and Fisheries Papers, No. 130, OECD Publishing, Paris.

ICF International 2013. Greenhouse Gas Mitigation Options and Costs for Agricultural Land and Animal Production within the United States. Report prepared for USDA, Climate Change Program Office. ICF International,Washington, DC.

IPCC 2006. 2006 IPCC Guidelines for National Greenhouse Gas Inventories, Prepared by the National Greenhouse Gas Inventories Programme. In: Eggleston H.S., Buendia L., Miwa K., Ngara T. \& Tanabe K. (eds). IGES, Japan.

Jones, C.A., Nickerson, C.J. \& Heisey, P.W. 2013. New uses of old tools? Greenhouse gas mitigation with agriculture sector policies. Applied Economic Perspectives and Policy 35: 398-434. https://doi.org/10.1093/aepp/ppt020

Kim, D.G., Saggar, S. \& Roudier, P. 2012. The effect of nitrification inhibitors on soil ammonia emissions in nitrogen managed soils: a meta-analysis. Nutrient Cycling in Agroecosystems 93: 51-64. https://doi.org/10.1007/s10705-012-9498-9

Kipling, R.P., Taft, H.E., Chadwick, D.R., Styles, D. \& Moorby, J. 2019. Challenges in implementing greenhouse gas mitigation measures in livestock agriculture: A conceptual framework for policymakers. Environmental Science and Policy 92: 107-115. https://doi.org/10.1016/j.envsci.2018.11.013

Kirk, G., Bellamy, P., Burgess, P., Coleman, K., Whitmore, A. \& Newell-Price, P. 2012. Quantification of the potential changes in soil carbon in England from soil protection measures within the Soil Protection Review 2010. Final report to Defra Sub-Project SP1106: Soil carbon studies to explore greenhouse gas emissions and mitigation, Defra, London.

Lal, R. 2004. Soil carbon sequestration to mitigate climate change. Geoderma 123: 1-22. https://doi.org/10.1016/j.geoderma.2004.01.032

Lankoski, J., Ollikainen, M. \& Uusitalo, P. 2006. No-till technology: benefits to farmers and the environment? Theoretical analysis and application to Finnish agriculture. European Review of Agricultural Economics 33: 193-221.https://doi.org/10.1093/erae/jbl003 Legume Futures 2014. Legume Futures Final Report 2014. SRUC, Edinburgh. www.legumefutures.de.

Lengers, B. \& Britz, W. 2012. The choice of emission indicators in environmental policy design: an analysis of GHG abatement in different dairy farms based on a bio-economic model approach. Review of Agricultural and Environmental Studies 93:117-144.

Lewandrowski, J., Peters, M., Jones, C., House, R., Sperow, M., Eve, M. \& Paustian, K. 2004. Economics of Sequestering Carbon in the U.S. Agricultural Sector. Technical Bulletin No. (TB1909). Washington, DC: U.S. Department of Agriculture, Economic Research Service.

Lötjönen, S. \& Ollikainen, M. 2017. Does Crop Rotation with Legumes Provide an Efficient Means to Reduce Nutrient Loads and GHG Emissions? Review of Agricultural, Food and Environmental Studies 98: 283-312. https://doi.org/10.1007/s41130-018-0063-z

Lötjönen, S. \& Ollikainen, M. 2019. Multiple-pollutant cost-efficiency: Coherent water and climate policy for agriculture. Ambio 48: 1304-1313. https://doi.org/10.1007/s13280-019-01257-z

Lötjönen, S., Temmes, E. \& Ollikainen, M. 2020. Dairy farm management when nutrient runoff and climate emissions count. American Journal of Agricultural Economics. https://doi.org/10.1002/ajae.12003

MacLeod, M., Eory, V., Gruère, G. \& Lankoski, J. 2015. Cost-Effectiveness of Greenhouse Gas Mitigation Measures for Agriculture: A Literature Review. OECD Food, Agriculture and Fisheries Papers, No. 89, OECD Publishing, Paris. https://dx.doi.org/10.1787/5jrvvkq900vj-en.

Manley, J., van Kooten, G.C., Moeltner, K. \& Johnson, D.W. 2005. Creating carbon offsets in agriculture through no-till cultivation: a meta-analysis of costs and carbon offsets. Climatic Change 68: 41-65. https://doi.org/10.1007/s10584-005-6010-4

Mason, C.F. \& Plantinga, A.J. 2011. Contracting for impure public goods: carbon offsets and additionality. Working Paper 564. Eni Enrico Mattei. https://doi.org/10.3386/w16963

McCarl, B.A. \& Schneider, U.A. 2001. Greenhouse gas mitigation in U.S. agriculture and forestry. Science 294: 2481-82. https://doi.org/10.1126/science.1064193

McKinsey \& Company 2009. Pathways to a low-carbon economy: Version 2 of the Global Greenhouse Gas Abatement Cost Curve, McKinsey \& Company, London.

McVittie, A., Ghaley, B. B., Molnar, A., Dibari, C., Karaczun, Z. \& Sanchez, B. 2014. Report on the cost-effectiveness of SOC measures. Edinburgh, Scotland; 2014.

Meurer, K.H.E., Haddaway, N.R., Bolinder, M.A. \& Kätterer, T. 2018. Tillage intensity affects total SOC stocks in boreo-temperate regions only in the topsoil - A systematic review usind ESM approach. Earth-Science Reviews 177: 613-622. https://doi.org/10.1016/j.earscirev.2017.12.015

Minasny, B., Malone, B.P., McBratney, A.B., Angers, D.A., Arrouays, D., Chambers, A., Chaplot, V., Chen, Z.-S.,Cheng, K., Dash, B.S., Field, D.J., Gimona, A., Hedley, C.B., Hong, S.Y., Mandal, B., Marchant, B.P., Martin, M., McConkey, B.G., Mulder, V.L., O'Rourke, S., Richer-de-Forges, A.C., Odeh, I., Padarian, J., Paustian, K., Pang, G., Poggio, L., Savin, I., Stolbovoy, V., Stockmann, U., Sulaeman, Y., Tsui, C.-C., Vågen, T.-G., Basvan Wesemael, B. \& Winowiecki, L. 2017. Soil carbon 4 per mille. Geoderma 292: 59-86. https://doi.org/10.1016/j.geoderma.2017.01.002 
Montserrat, A. \& Sohngen, B. 2009. How big is leakage from forestry carbon credits? Estimates from a global model. IOP Conference Series: Earth and Environmental Science 6: 052011. https://doi.org/10.1088/1755-1307/6/5/052011

Moran, D., MacLeod, M., Wall, E., Eory, V., Pajot, G., Matthews, R., McVittie, A., Barnes, A., Rees, B., Moxey, A. \& Williams, A. 2008. UK marginal abatement cost curves for the agriculture and land use, land-use change and forestry sectors out to 2022 with qualitative analysis of options to 2050. Final Report. UK Committee on Climate Change, London, UK. https://doi.org/10.1088/1755-1307/6/24/242002

Murray, B.C. \& Baker, J.S. 2011. An output-based intensity approach for crediting greenhouse gas mitigation in agriculture: explanation and policy implications. Greenhouse gas Measurement and Management 1: 27-36. https://doi.org/10.3763/ghgmm.2010.0004

Nemecek, T., von Richthofen, J.S., Dubois, G., Casta, P., Charles, R. \& Pahl, H. 2008. Environmental impacts of introducing grain legumes into European crop rotations. European Journal of Agronomy 28: 380-393. https://doi.org/10.1016/j.eja.2007.11.004

Niles, M.T., Waterhouse, H., Parkhurst, R., McLellan, E.L. \& Kroopf, S. 2019. Policy options to streamline the carbon market for agricultural nitrous oxide emissions. Climate Policy 19: 893-907. https://doi.org/10.1080/14693062.2019.1599802

OECD 2019. Enhancing Climate Change Mitigation through Agriculture, OECD Publishing, Paris. https://doi.org/10.1787/e9a79226-en

Ogle, S.M., Alsaker, C., Baldock, J., Bernoux, M., Breidt, F.J., McConkey, B., Regina, K. \& Vazquez-Amabile, G.G. 2019. Climate and soil characteristics determine where no-till management can store carbon in soils and mitigate greenhouse gas emissions. Scientific Reports 9: 11665. https://doi.org/10.1038/s41598-019-47861-7

Ollikainen, M., Hasler, B., Elofsson, K., Iho, A., Andersen, H., Czajkowski, M. \&Peterson, K. 2019. Toward the Baltic Sea Socioeconomic Action Plan. Ambio 48: 1377-1388. https://doi.org/10.1007/s13280-019-01264-0

Pattanayak, S.K., McCarl, B.A., Sommer, A.J., Murray, B.C., Bondelid, T., Gillig, D. \& Deangelo, B. 2004. Water quality co-effects of greenhouse gas mitigation in U.S. agriculture. Climatic Change 71: 341-372. https://doi.org/10.1007/s10584-005-5925-0

Pellerin, S., Bamiere, L., Angers, D., Béline, F., Benoit, M., Butault, J.P., Chenu, C., Colnenne-David, C., De Cara, S., Delame, N. \& Doreau, M. 2013. How can French agriculture contribute to reducing greenhouse gas emissions? Abatement potential and cost of ten technical measures. Synopsis of the study report, INRA (France).

Perez Dominguez, I. \& Britz, W. 2003. Reduction of global warming emissions in European agriculture through a tradable permit system: An analysis with the regional agricultural model CAPRI. Schriften der Gesellschaft für Wirtschafts- und Sozialwissenshaften des Landbaus e. 39: 283-290.

Post, M. 2012. Cultured meat from stem cells: Challenges and prospects. Meat Science 92: 297-301. https://doi.org/10.1016/j.meatsci.2012.04.008

Posthumus, H., Deeks, L.K., Rickson, R.J. \& Quinton, J.N. 2013. Costs and benefits of erosion control measures in the UK. Soil Use and Management 31: 16-33. https://doi.org/10.1111/sum.12057.

Povellato, A., Bosello, F. \& Giupponi, C. 2007. Cost-effectiveness of greenhouse gas mitigation measures in the European agroforestry sector: a literature survey. Environmental Science \& Policy 10: 474-490. https://doi.org/10.1016/j.envsci.2007.02.005

Powlson, D.S., Stirling, C.M., Jat, M.L., Gerard, B.G., Palm, C.A., Sanchez, P.A. \& Cassman, K.G. 2014. Limited potential of no-till agriculture for climate change mitigation. Nature Climate Change 4: 678-683. https://doi.org/10.1038/nclimate2292

Regina, K., Kaseva, J. \& Esala, M. 2013. Emissions of nitrous oxide from boreal agricultural mineral soils -statistical models based on measurements. Agriculture, Ecosystems \& Environment 164: 131-136. https://doi.org/10.1016/j.agee.2012.09.013

Rickertsen, K., Kristofersson, D. \& Lothe, S. 2003. Effects of health information on Nordic meat and fish demand. Empirical Economics 28: 249-273. https://doi.org/10.1007/s001810200129

Rose, S.K., Ahammad, H., Eickhout, B., Fisher, B., Kurosawa, A., Rao, S., Riahi, K. \& van Vuuren, D.P. 2012. Land-based mitigation in climate stabilization. Energy Economics 34: 365-380. https://doi.org/10.1016/j.eneco.2011.06.004

Säll, S. \& Gren, I.-M. 2015. Effects of an environmental tax on meat and dairy consumption in Sweden. Food Policy 55: 41-53. https://doi.org/10.1016/j.foodpol.2015.05.008

Schulte, R., Crosson, P., Donnellan, T., Farrelly, N., Finnan, J., Lalor, S., Lanigan, G., O’Brien, D., Shalloo, L., Thorne, F., Boland, A., Caslin, B., Fealy, R., Foley, M., Gibson, M., Humphreys, J., Hanrahan, K., Hyde, T., Kelly, P., Maher, P., Murphy, P., NiFhlatharta, N., O'Donoghue, C., O'Kiely, P., Richards, K., Spink, J. \& O'Mara, F. 2012. A Marginal Abatement Cost Curve for Irish Agriculture. In: Schulte, R. \& Donnellan, T. (eds.) Teagasc submission to the National Climate Policy Development Consultation. Teagasc, Dublin Ireland. $91 \mathrm{p}$.

Smith, P., Martino, D., Cai, Z., Gwary, D., Janzen, H., Kumar, P., McCarl, B., Ogle, S., O’Mara, F., Rice, C. \& Scholes, B. 2008. Greenhouse gas mitigation in agriculture. Philosophical Transactions of the Royal Society B: Biological Sciences 363: 789-813. https://doi.org/10.1098/rstb.2007.2184

Smith, P., Bustamante, M., Ahammad, H., Clark. H., Dong, H., Elsiddig, E.A., Haberl, H., Harper, R., House, J., Jafari. M., Masera, O., Mbow, C., Ravindranath, N.H., Rice, C.W., Abad, C. R., Romanovskaya, A., Sperling, F. \& Tubiello, F. 2014. Agriculture, Forestry and Other Land Use (AFOLU). In: Edenhofer, O., Pichs-Madruga, R., Sokona, Y., Farmhand, E., Kadner, S., Seyboth, K., Adler, A Baum, I., Brunner, S., Eickemeier, P., Kriemann, B., Savolainen, J., Schlömer. S., von Stechow, C., Zwickel, T. \& Minx, J.C. (eds.) Climate Change 2014: Mitigation of Climate Change. Contribution of Working Group III to the Fifth Assessment Report of the Intergovernmental Panel on Climate Changel. Cambridge University Press, Cambridge, UK and New York, NY, USA.

Smith, P. 2012. Agricultural greenhouse gas mitigation potential globally, in Europe and in the UK: what have we learnt in the last 20 years? Global Change Biology 18: 35-43. https://doi.org/10.1111/j.1365-2486.2011.02517.x

Smith, P. 2016. Soil carbon sequestration and biochar as negative emission technologies. Global Change Biology 22: 1315-1324. https://doi.org/10.1111/gcb.13178 
Statistics Finland 2016. Greenhouse gas emissions in Finland 1990-2014. National inventory report under the UNFCCC and the Kyoto protocol, 15 June 2016. Statistics Finland.

Valkama, E., Lemola, R., Känkänen, H. \& Turtola, E. 2015. Meta-analysis of the effects of undersown catch crops on nitrogen leaching loss and grain yields in the Nordic countries. Agriculture, Ecosystems \& Environment 203: 93-101.

https://doi.org/10.1016/j.agee.2015.01.023

Vermont, B. \& De Cara, S. 2010. How costly is mitigation of non- $\mathrm{CO}_{2}$ greenhouse gas emissions from agriculture?: A meta-analysis. Ecological Economics 69: 1373-1386. https://doi.org/10.1016/j.ecolecon.2010.02.020

Webb J., Pain, B., Bittman, S. \& Morgan, J. 2010. The impacts of manure application methods on emissions of ammonia, nitrous oxide and on crop response - A review. Agriculture, Ecosystems \& Environment 137:39-46.

https://doi.org/10.1016/j.agee.2010.01.001

Wiltshire. J. et al. 2014. Assessment of the Effectiveness, Impact and Cost of Measures to Protect Soils: Report for Defra. Ricardo-AEA Ltd, Didcot, UK.

Wirsenius, S., Hedenus, F. \& Mohlin, K. 2011. Greenhouse gas taxes on animal food products: rationale, tax scheme and climate mitigation effects. Climatic Change 108: 159-184. https://doi.org/10.1007/s10584-010-9971-x

Wreford, A., Ignaciuk, A. \& Gruère, G. 2017. Overcoming barriers to the adoption of climate friendly practices in agriculture. OECD Food, Agriculture and Fisheries Papers, No. 101, OECD Publishing, Paris. https://doi.org/10.1787/97767de8-en 